Таким образом, изложенное даёт основание утверждать, что подвергнутые в настоящей работе анализу проблемы, заслуживают внимания не только на теоретическом уровне, но и требует своего разрешения посредством нормотворчества. Однако в первую очередь, полагаю, целесообразным будет все-таки признать, что прокурорский надзор за исполнением законов органами, осуществляющими ОРД, является самостоятельной отраслью надзора в структуре деятельности прокуратуры Российской Федерации.

$$
\text { *** }
$$

1. Об организации прокурорского надзора за исполнением законов при осуществлении оперативнорозыскной деятельности: приказ Генерального прокурора Рос. Федерации от 15 февр. 2011 г. № 33. П. 4.

2. Федеральный закон от 17 января 1992 г. N 2202-1 "О прокуратуре Российской Федерации" (по состоянию на 25.10.2016) // СПС "КонсультантПлюс"

3. Федеральный закон от 12 августа 1995 г. N 144-Ф3 "Об оперативно-розыскной деятельности" (по состоянию на 06.07.2016) //СПС "КонсультантПлюс"

4. Доклад Ю. Я. Чайки на расширенном заседании коллегии Генеральной прокуратуры Российской Федерации / Сайт Генеральной прокуратуры Российской Федерации. URL: http://genproc.gov.ru/genprokuror/appearances/document-493/

5. Козусев А. Ф. Надзор за исполнением законов в оперативно-розыскной деятельности - отрасль прокурорского надзора // Проблемы теории и практики прокурорского надзора в современных условиях: тезисы науч.-практ. конференции /Акад. Генеральной прокуратуры Рос. Федерации. М., 2005. Ч. 1. С. 75 .

6. Никитин Е.Л. О задачах оперативно-розыскной деятельности и особенностях предмета прокурорского надзора за исполнением законов в ОРД// Криминалистъ. 2015. №2 (17). С.34-39.

7. Никитин Е.Л., Дытченко Г.В. Современная парадигма прокурорского надзора за исполнением законов в оперативно-розыскной деятельности // КриминалистЪ. 2014. №1 (14). С. 73-80.

\title{
Халиулова И.Р. \\ Особенности правовой основы реформы Д.А. Милютина 1860-1870-х гг. В области военного образования
}

Ульяновский государственньій университет (Россия, Ульяновск)

doi:10.18411/spc-20-11-2017-19

idsp: 000001:spc-20-11-2017-19

\section{Аннотация}

В статье дана характеристика реформаторской деятельности военного министра Д.А. Милютина в сфере военного образования. Раскрываются причины проведения реформ 60-70-х гг. XIX в., перечислены основные нормативно-правовые источники реформы военного образования.

Ключевые слова: военная реформа Александра II, Д.А. Милютин, военное образование, военные гимназии и прогимназии, военные и юнкерские училища.

Социально-экономический кризис в Российской империи, поразивший основные сферы жизнедеятельности российского обществав 40-50-х гг. XIX в. отразился, в том числе, и на состоянии русской армии, что предопределило поражение России в Крымской войне 1853-1855 гг.

Наряду с другими объективными и субъективными условиями и факторами, предопределившими деградацию русской армии в первой половине XIX в., необходимо выделить сознательный отказ Императора от национальной военной стратегии, а также его ориентацию на чуждые национальной военной традиции принципы подготовки вооружённых сил.

Крымская война стала суровым испытанием для всей военной системы Российского государства, в том числе, для системы подготовки офицерских кадров. Её состояние на основе итогов войны образно, но в то же время вполне объективно оценил 
в своём исследовании П.Ф. Заусцинский: «Несмотря на огромные личные и материальные средства России, на пламенный патриотизм населения, на беспримерное самоотвержение армии, Россия вынуждена была уступить. Вооружение войск оказалось никуда негодным, обучение их поверхностным и не боевым; управление ими в бою не выдерживающим самой снисходительной критики; снабжение их боевыми и жизненными средствами плохим; лечение недостаточным; пополнение убыли неорганизованным. Все строевые чины армии, от генерала до солдата, умели геройски умирать за царя и Отечество, но, за очень немногими исключениями, не умели сражаться» [8; С. 308].

Таким образом, требовались глубокие структурные преобразования в подготовке офицерских кадров. Они были осуществлены военным министром Дмитрием Алексеевичем Милютиным, который рассматривал повышение профессиональной подготовки офицеров как первоочередную задачу. Для реализации данной цели министром были привлечены такие компетентные военные специалисты как В.М. Аничков, М.И. Драгомиров, Н.Н. Обручев и др.

Характеризуя офицерский состав русской армии дореформенной эпохи, необходимо отметить, что военно-учебные заведения ежегодно давали не более $26 \%$ офицеров, поступавших на укомплектование армии. Около 62\% офицеров были выходцами из юнкеров и унтер-офицеров, остальные $12 \%$ поступали из отставных[9; С. 34-35]. И это несмотря на то, что в царствование Николая I произошло расширение сети военно-учебных заведений и повышение уровня военного образования[14; С. 217]. До этого времени учебные заведения не имели между собой ничего общего, система воспитания и учебные предметы были различными, не имелось прочно установившихся программ. Д.А. Милютин писал, что «..ни молодые офицеры, ни старые начальники не имели понятия о тактике своего оружия, не говоря уже о других военных науках..» [6; C. 316].

В1863 г. итогом реформаторской инициативы было учреждение специального комитета «с целью содействовать ему в предварительном обсуждении об окончательном решении вопросов хозяйственного устройства, воинского образования и внутренней службы войск»[10; С. 603], а результатом работы стало принятие основных положений будущей реформы. Данные положения предусматривали отделение в кадетских корпусах специальных классов от общих для того, чтобы на их базе были в дальнейшем созданы военно-учебные заведения нового образца. Согласно данным юридическим документам, предполагалось, что в военно-учебных заведениях будет осуществляться подготовка не только для специальных родов войск - артиллерийских и инженерных, но и для армейских войск - пехоты и кавалерии, а также будут открыты юнкерские школы при войсках[3; С. 51].

В том же году было принято Положение о Главном управлении военно-учебных заведений, согласно которому управление всеми военно-учебными заведениями было сосредоточено в Военном министерстве[10; С. 603]. Одновременно с реорганизацией военно-учебных заведений совершенствовалась правовая база, которая регулировала вопросы жизнедеятельности учебных заведений. Итогом этой работы явилось принятие в новой редакции Свода военных постановлений, в частности, книги 15-й «Заведения военно-учебные» $[13 ;$ Ст. 13,18].

В1864 г. был создан новый тип школы - юнкерские училища, которые создавались в целях «...доставления низшим чинам регулярных войск и урядникам из дворян и обер-офицерских детей иррегулярных войск научного и строевого образования, необходимого для офицера». В 1865 г. были открыты 4 пехотных и 2 кавалерийских юнкерских училища[8; С. 246].

Говоря о значении юнкерских училищ, генерал-адъютант Д.А. Милютин в отчёте Венного министерства за 1865 г. писал: «Открытие юнкерских училищ принято 
было в армии с большим сочувствием. Настоятельная потребность в этих заведениях давно осознана у нас всеми» [4; С. 98].

Первоначально юнкерские училища создавались при корпусных штабах, они не имели единой организации. С 1864 г. училища стали подчиняться непосредственно военным округам, а в учебном отношении - Главному управлению военно-учебных заведений[1; С. 7]. С принятием Положения о юнкерских училищах 16 марта 1868 г. данные учебные заведения приобрели более стройную организацию. Сословный состав юнкерских училищ очень сильно отличался от состава военных училищ. К концу XIX в. почти половину обучающихся в юнкерских училищах составляли дети крестьян, мещан и казаков.

В 1863 г.было начато преобразование общих классов кадетских корпусов в военные гимназии[11; С. 942]. В1864 г. были преобразованы в военные гимназии общие классы Первого кадетского, Первого и Второго московских корпусов, Орловского - Бахтина и Тульского - Александровского кадетских корпусов[2; С. 147]. В течение 1865 и 1866 гг. на базе кадетских корпусов открылось 12 военных гимназий[5; С. 171]. Остальные кадетские корпуса, за исключением Пажеского и Финляндского, были упразднены. В конце 1866 г. вышло Положение о военных гимназиях. «Военные гимназии, - говорилось в нём, - имеют целью доставить детям потомственных дворян, предназначенным к военной службе, приготовительное общее образование и воспитание»[12; С. 1157].

Наряду с военными гимназиями в 1868 г., были созданы и военные прогимназии на основе преобразования военно-начальных школ, которые возникли в 1858 г. из бывших батальонов военных кантонистов, призванных давать образование детям беднейших дворян и заслуженных нижних чинов. Прогимназии готовили своих воспитанников к поступлению в юнкерские училища.

Положением, утверждённым в апреле 1869 г. и введённым в действие приказом военного министра №172 (1869 г.), военные прогимназии получили общеобразовательный статус.

Таким образом, за короткий по историческим меркам период военное образование России претерпело кардинальные изменения. К началу 70-х гг. XIX столетия в результате преобразования военно-учебных заведений была создана стройная система военного образования. Д.А. Милютин писал: «В дальнейшем работа Военного министерства относительно устройства военно-учебных заведений была направлена на изменение правил приёма в военные училища с целью согласования с новым Уставом о воинской повинности» [6; С. 306].

Преобразованиям в сфере военного образования сопутствовал серьёзный труд по разработке нормативно-правовых источников.

\section{$* * *$}

1. Бобровский П.О. Юнкерские училища. Т. 2. Ч. 3: Обучение и военное воспитание юнкеров / П.О. Бобровский. - СПб.: Я. А. Исаков, 1873. - 685 с.

2. Богданович М.И. Исторический очерк деятельности военного управления в России (1855-1880 гг.). Том 4 / М.И. Богданович. - СПб.: Тип. М. Стасюлевича, 1901. - 603 с.

3. Всеподданнейший отчёт о действиях военного министерства за 1863 год. - СПб.: Военная Типография, 1864. - 460 с.

4. Всеподданнейший отчёт о действиях военного министерства за 1865 год. - СПб.: Военная Типография, $1866 .-571 \mathrm{c.}$

5. Всеподданнейший отчёт о действиях военного министерства за 1866 год. - СПб.: Военная Типография, 1867. - 307 с.

6. Дневник генерал-фельдмаршала графа Дмитрия Алексеевича Милютина, Том 4. - М.: РОССПЭН, 2010. - 582 с.

7. Зайончковский П.А. Военные реформы 1860-1870 годов в России / П.А. Зайончковский. - М.: Издательство Московского университета, 1952. - 375 с.

8. Заусцинский П.Ф. История кодификации русского военного права в связи с историей развития русского войска до реформ ХІХ века / П.Ф. Заусцинский. - СПб.: Воен. тип., 1909. - 548 с. 
9. Мельницкий Н.Н. Сборник сведений о военно-учебных заведениях в России (сухопутного ведомства): в 4 т.: в 6 ч. Т. 1: Ч. 1 / Н.Н. Мельницкий. - СПб.: Воен. тип., 1860. - 139 с.

10. Полное собрание законов Российской Империи. Собрание Второе. Том ХХХІІ. Отделение 2. 1857 г. - СПб.: Тип. II Отделения Собственной Его Императорского Величества Канцелярии, 1858. - 864 с.

11. Полное собрание законов Российской Империи. Собрание Второе. Том XXXVIII. Отделение 1. 1863 г. - СПб.: Тип. II Отделения Собственной Его Императорского Величества Канцелярии, 1866. - 942 c.

12. Полное собрание законов Российской Империи. Собрание Второе. Том XLI. Отделение 2. 1866 г. СПб.: Тип. ІІ Отделения Собственной Его Императорского Величества Канцелярии, 1868. - 1411 с.

13. Свод военных постановлений 1869 года: Ч.2. Комплектование войск и управлений, заведений и учреждений военного ведомства (по 1 января 1907 года) Кн. 5 Устройство и состав войск и управление ими. - СПб.: Государственная типография, 1907. - 304 с.

14. Скобликов С.В. Социально-правовое положение воинского сословия в России во второй половине XIX - начале XX в. / С.В. Скобликов // Известия Алтайского государственного университета. 2015. - T. 2. №3(87). - С. 215-217.

\section{Чуева А.С., Чиж А.А., Семиков Ю.В. \\ К вопросу об особенностях организации местного самоуправления в городах федерального значения (Москве, Санкт-Петербурге, Севастополе) \\ «Кубанский государственный аграрный университет имени И.Т. Трубилина» (Россия, Краснодар)}

doi:10.18411/spc-20-11-2017-20

idsp: 000001:spc-20-11-2017-20

Известно, что особенность организации местного самоуправления на той или иной территории обусловлена, прежде всего, видом (типом) муниципального образования, а также отличительными чертами его правового статуса, закрепляемого федеральными законами, историческими и иными местными традициями, географическими особенностями, численностью населения, социальноэкономическими характеристиками, другими факторами.

В рамках данной статьи нами будут рассмотрены особенности организации местного самоуправления в городах федерального значения. Напомним, что согласно ст. 65 Конституции РФ [1]городами федерального значения являются: Москва, СанктПетербург и Севастополь. Это крупнейшие мегаполисы со сложной социальноэкономической инфраструктурой, имеющие статус субъектов Федерации. Однако, в отличие от иных регионов, внутри названных городов образованы внутригородские территории, на которых осуществляется местное самоуправление.

На наш взгляд, особую актуальность имеют положения ст. 79 Федерального закона от 6 октября 2003 года №131-Ф3 «Об общих принципах организации местного самоуправления в Российской Федерации» [2] (далее Федеральный закон №131-Ф3, Закон 2003), регламентирующие особенности организации местного самоуправления в городах федерального значения, что, в свою очередь, обусловлено статусом этих городов.

Так, Федеральный закон №131-Ф3 устанавливает, что в Москве, СанктПетербурге и Севастополев соответствии с уставами указанных субъектов РФ местное самоуправление осуществляется органами местного самоуправления на внутригородских территориях. Установление и изменение границ внутригородских муниципальных образований, их преобразование осуществляются законами названных городов федерального значения с учетом мнения населения соответствующих внутригородских территорий.

Перечень вопросов местного значения, источники доходов местных бюджетов внутригородских муниципальных образований городов федерального значения определяются соответственно законами Москвы, Санкт-Петербурга и Севастополя исходя из необходимости сохранения единства городского хозяйства. Установленные Федеральным законом №131-Ф3, другими федеральными законами источники доходов местных бюджетов, не отнесенные законами субъектов РФ (городов федерального значения - Москвы, Санкт-Петербурга, Севастополя) к источникам доходов бюджетов 